\title{
Study on the development of nanotechnology in advanced countries and in Brazil
}

\author{
Carolina Fracalossi Rediguieri*
}

National Health Surveillance Agency

\begin{abstract}
The study shows how nanotechnology evolves in developed countries and Brazil, raising aspects of private and governmental initiatives. The investigation was based in scientific literature, electronic articles and conference reports. Several sources of literature were used, including electronic databases and reference lists. By this study, it was observed that, although nanotechnology is in initial stage of development all over the world, the developed countries have had growing public and private investments in the area each year. In those countries, there is a concern toward both, the formation of specialists in nanotechnology and the transference of technology developed in universities and research institutes to industry. In Brazil, the study showed that despite the growing concern of investigators, national research centers and financial centers toward the development of the nanotechnology, there is still a need for more investment and formation of area specialists.
\end{abstract}

Uniterms: Nanotechnology/development. Nanobiotechnology. Nanopharmaceutical.

O presente trabalho faz um estudo sobre o desenvolvimento da nanotecnologia, com enfoque na área de saúde, em países tecnologicamente mais avançados e no Brasil, levantando aspectos de iniciativas governamentais e privadas. A investigação foi baseada em literatura científica, artigos eletrônicos e relatórios de conferências. Foi observado que, apesar da nanotecnologia estar em estágio inicial no mundo inteiro, os países tecnologicamente mais avançados têm tido investimentos crescentes na área a cada ano, tanto públicos quanto privados. Há grande preocupação nesses países quanto à formação de profissionais especialistas na área e à transferência da tecnologia desenvolvida por universidades e institutos de pesquisa para a indústria. No Brasil, o estudo mostrou que apesar da crescente preocupação dos pesquisadores, centros de pesquisa e centros de financiamento com o desenvolvimento da nanotecnologia, ainda há necessidade de maiores investimentos e formação de profissionais especialistas na área.

Unitermos: Nanotecnologia/desenvolvimento. Nanobiotecnologia. Nanofármaco.

\section{INTRODUCTION}

The nanotechnology is nowadays an emerging technology; no more just a vision for future, as it was seen at the end of $20^{\text {th }}$ century, with potential to impact every aspect of modern human civilization. The more diverse areas will be affected, such as agriculture, communication, energy generation/transmission, informatics, environmental monitoring, food manufacturing/processing, health, personal care, astronautics, robotics, but probably the strongest impact will be in medicine (Roszeki, De Jonga, Geertsma, 2005).

*Correspondence: C. F. Rediguieri. Agência Nacional de Vigilância Sanitária, S I A, Trecho 5, Área Especial 57 - Bloco B - 71205-050 - Brasília - DF, Brasil. E-mail: rediguieri@yahoo.com.br
The nanotechnology is currently one of the main focuses of Science, Technology and Innovation (C\&T\&I) activities in all industrialized countries. The investments in the area have been growing and achieved worldwide five billion dollars in 2002. There are estimates that from 2010 to 2015, the world market for industrial materials, products and processes based on nanotechnology will be of one trillion dollars. This voluminous production will be distributed over practically all economics sectors, because the nanotechnology will affect a great number of industrial products and processes, in all areas, besides creating new service activities (Dos Anjos, Tavares, Mendes, 2004).

Beyond the vast industrial use of nanotechnology, great innovations are anticipated in medicine, having their predominance in diagnosis, monitoring, more durable 
prosthesis, and new drug delivery systems. The pharmaceutical sector occupies the third place in the foreseen ranking of the largest nanotechnology markets in 2015.

When applied to biomedical sciences, such as medicine and pharmaceutics, the nanotechnology receives the name of nanobiotechnology (Com Ciência, 2002a).

In regions of more advanced technology, such as USA and Europe, it is perceived a larger concern for the nanotechnology development. A study developed by the European Science Foundation shows the strengths, weaknesses, opportunities and threats for the development of such technology in the region. In terms of research, for instance, there are in Europe many academic groups leading the subdisciplines of nanobiotechnology with expertise in delivery systems and clinical development of nanodrugs. However, they face the problem of brain drain, with the migration of young scientists to the USA (European Science Foundation, 2004).

In the past Brazil used to be a mere spectator of the great technological advances. The change in old paradigms of sciences and the technology exchange enabled by the world wide web have favoured Brazil and other developing countries (Com Ciência, 2002b). In this context, the Ministry of Science and Technology (Ministério da Ciência e Tecnologia - MCT)/National Council of Scientific and Technological Development (Conselho Nacional de Desenvolvimento Cientifico e Tecnológico - $\mathrm{CNPq}$ ) has taken the initiative and created in 2003, the General Coordination of Nanotechnology. Besides, it has created a multidisciplinary and multisectorial work group (Grupo de Trabalho - GT) to elaborate a national program of Research and Development (R\&D) in Nanosciences and Nanotechnologies (N\&N), identifying the real needs to foster the development of nanotechnology in Brazil to enable the country to be competitive in the international market.

There is currently a significant scientific production in Brazil, with great number of university laboratories investigating the area of nanotechnology (Galembeck, 2005), in themes such as nanoobjects manipulation, nanoelectronics, nanobiotechnology, which includes nanodrugs, nanocatalysis and the nanocomposites (Dos Anjos, Tavares, Mendes, 2004).

This present work makes an analysis about how nanotechnology is being developed in more technologically advanced countries and in Brazil as well, focusing as much as possible on health, and raising aspects of governmental and private initiatives.

This investigation was based on scientific literature, electronic articles and conference reports. The literature was identified from several sources, including electronic databases and reference lists.

\section{DEVELOPMENT OF NANOTECHNOLOGY IN ADVANCED COUNTRIES}

The nanotechnology is still in initial phase of development all over the world. The current role of federal funding for the research and development in this area is to provide the bases for elementary research, on which the future technologies of nanometric scale will be established. The elementary research is necessary to improve the basic understanding in several fields of science and engineering, as well as to provide new approaches for the synthesis, analysis and manufacturing of products based on nanotechnologies. The development of new devices enabling precise measurements and manipulation within the nanometric scale is a current and actual challenge (Inovação, 2004).

Challenges as such present also different opportunities; for instance, to develop interdisciplinary projects among different agencies, leading to the merge of traditional lines of investigation and creation new ones; the opportunity to refresh Chemistry and Physics, bringing these disciplines to the dimension where singular properties of nanometric objects take place and, not coincidently, to the functioning level of biological systems; and opportunities to develop new engineering systems and instrumentation that could be used to handling and measure nanostructure properties, including biological systems that were few time ago, beyond our means.

Because of this complexity, and the high cost and risk associated with nanotechnological investigations, the private sector, frequently, is not able to assure of its own accord the return of investments in short or middle term for this specific R\&D field. Consequently, it is improbable that the industry develops the investments in basic research required to overcome the existing technical barriers (Inovação, 2004).

On the other hand, the industry is increasingly confident in the differentiated possibilities of this technology. Just to contextualize a little better, it is estimated that within 10 to 15 years the annual production of the nanotechnology sector should overcome the rate of one trillion dollars, requiring about two million employees (Alves, 2004). At least 30 countries have started national activities in this field.

The Europe, Japan and United States (USA) have the higher governmental investments; being that from 2001 to 2003 Japan has invested a little more than the other two great actors (ETC Group, 2005).

Table I shows the amount of governmental investiments in R\&D done by the major stakeholders.

There is a growing trend of nanotechnology investments all over the world. When comparing the amount 
TABLE I - R\&D governmental investments in nanotechnology, 2000-2003

\begin{tabular}{lcccc}
\hline Region & \multicolumn{4}{c}{ Approximate amount invested (million dollars/year) } \\
\cline { 2 - 4 } & $\mathbf{2 0 0 0}$ & $\mathbf{2 0 0 1}$ & $\mathbf{2 0 0 2}$ & $\mathbf{2 0 0 3}$ \\
\hline Europe & 200 & $\sim 225$ & $\sim 400$ & $\sim 600$ \\
Japan & 245 & $\sim 465$ & $\sim 700$ & $\sim 810$ \\
United States & 270 & 422 & 697 & 774 \\
Others* & 110 & $\sim 380$ & $\sim 550$ & $\sim 800$ \\
Total & $\mathbf{8 2 5}$ & $\mathbf{1 4 9 2}$ & $\mathbf{2 3 4 7}$ & $\mathbf{2 9 8 4}$ \\
\% 1997 & $191 \%$ & $346 \%$ & $502 \%$ & $690 \%$ \\
\hline
\end{tabular}

* Other includes Australia, Canada, China, Eastern Europe, Israel, Korea, Singapore, Taiwan and remaining countries with nanotechnology R\&D programs. Source: Alves, 2004.

invested by governmental entities in 2003 with the amount invested in 1997, it is perceived an increase along those years of approximately six times. However, it is also observed an enormous gap between the amount of investments of West -Europe, Japan and USA, when compared to other countries (including Australia, Canada, China, Eastern Europe, Israel, Korea, Singapore, Taiwan and remaining countries with nanotechnology R\&D programs).

In 2004, the worldwide investment in nanotechnology from private and public sectors, was estimated in US $\$ 8.6$ billion (ECT Group, 2005). From that year on,
USA started to lead the team of countries that more intensively invest in this area, a leadership previously occupied by Japan, up to 2003 . Figure 1 depicts the public and private investments done in nanotechnology R\&D at EU, USA, Japan and other countries, in the year of 2004.

It is interesting to observe that in USA and Japan, which are the countries with higher investments in nanotechnology, the larger part of investments comes from the private sector. However, in general, the public investments are higher than the private ones, in the major part of the world.

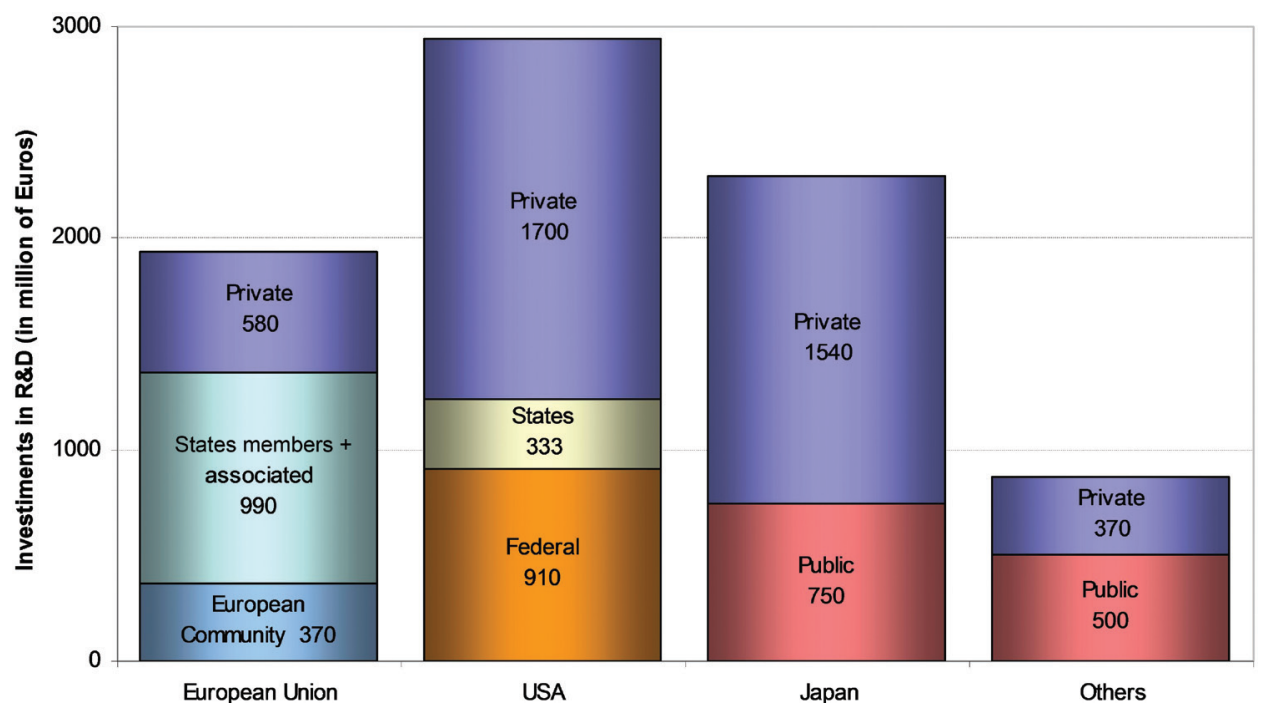

Investments in R\&D (in million of Euros)

Private; State members + associated; European Community

Private; States; Federal

Private; Public

Private; Public

European Union, USA, Japan, Other

FIGURE 1 - Public and private investments in nanotechnology R\&D, in the year of 2004. Source: UNIT G4, 2005. 


\section{United States}

In the last three years, the nanotechnology has firmed itself as one of the priorities for the American investments. It started to receive higher attention during the government of President Bill Clinton, in the 90s, due to endeavor from that time Vice-President Al Gore (Com Ciência, 2002c). In 2001, the American government has created a great program named National Nanotechnology Initiative (NNI), with the purpose to coordinate the R\&D of nanoscale science, engineering and technology (The National Nanotechnology Initiative, 2004). Nowadays 25 agencies are part of that program, being that 13 of them invest in R\&D of nanotechnology (The National Nanotechnology Initiative, 2006). Among these agencies are: National Aeronautics and Space Administration (NASA), National Institute for Occupational Safety and Health (NIOSH), National Institutes of Health (NIH), National Science Foundation (NSF), Food and Drug Administration (FDA), U.S. Patent and Trademark Office (USPTO, Department of Commerce), and others (The National Nanotechnology Initiative, 2004).

The investigation agenda for the agencies participating of NNI is coordinated by the Subcommittee of Nanoscience and Nanoengineering (Nanoscale Science and Engineering Technology - NSET) of the National Science and Technology Council (NSTC). The NSTC is an interagency organism of ministerial level, through which the science and technology themes from agencies are discussed and coordinated. The NSET is formed by representatives from participant agencies, the Office of Science and Technology Policy (OSTP) and of Office of Management and Budget (OMB). The Subcommittee includes also other federal agencies that do not fund Nanotechnology R\&D, but have interest in these technologies - such as FDA and the Treasure Department. The members of NSET meet once a month to evaluate the progress, establish priorities, organize work meetings and plan the following year.

The funding for NNI supports an ample extent of activities, such as basic research, which concentrates efforts to answer questions of great significance, the so called "Great Challenges"; as well as the construction of research infrastructure (instrumentation, equipment, facilities), excellence centers and network (larger and centralized facilities, with the purpose to provide spaces for cooperative and collaborative efforts between investigator networks and groups in the many affiliated institutions). Depending on the agency, the fund supports investigation oriented to specific internal missions, research in national laboratories, academic or other institutions. Part of the funding is also addressed to approach non-technical research problems in a broader context, including social implications and staff training (Inovação, 2004).

The targets of NNI are: a) advance a world-class nanotechnology research and development program; b) foster the transfer of new technologies into products for commercial and public benefit; c) develop and sustain educational resources, a skilled workforce, and the supporting infrastructure and tools to advance nanotechnology; d) support responsible development of nanotechnology.

The investments from USA government in the area of nanoscience and nanotechnology $(\mathrm{N} \& \mathrm{~N})$ are progressively increasing every year (Table 1 ). The budget for the year of 2006 had an increase of $8.3 \%$ when compared to 2005. For 2007, the budget was 1.3 billion dollars (Budget, 2007).

The NNI aroused also the interest from regional, state and local authorities to invest in this area. These authorities aim to obtain the economical benefits from research in nanotechnology, as well as its commercialization. It is estimated that these investments attain a total of $20 \%$ of federal investments. As presented at Figure 1, the private sector is also investing in $\mathrm{R} \& \mathrm{D}$, in an equal or higher level than federal government.

This entire policy has the purpose to maintain the American position on the top of the list of new technological discoveries (The National Nanotechnology Initiative, 2004).

The investment strategy of NNI is done through major subject areas, the so called Program Component Areas (PCAs). The Program Component Areas are: a) fundamental nanoscale phenomena and process; b) nanomaterials; c) nanoscale devices and systems; d) instrumentation research, metrology, and standards for nanotechnology; e) nanomanufacturing; f) major research facilities and instrumentation acquisition; g) social dimensions. Every PCA may include researches varying from the basic to applied, as well as the development of applications based in nanotechnology.

Because they are quite recent, newer than 10 years, the investments and researches in N\&N in the USA, summing private and public resources, have not reached the same amount of resources as the Genome Project, for instance; which is treated as a priority. The expectation for the future of $N \& N$ is that it achieves the same status of genetics, because with its multidisciplinary character, it embraces areas from the Genome Project itself. In this phase of "advertising", the N\&N is being assimilated by the society. A majority of experiments is still in phase of tests, but the conception of N\&N has already ample divulgence. The maturing time for the practical applications 
varies according the research area. The nanotechnology of materials for the production of polymers, for instance, should arrive to market in one or two years, while the technology for electronics and drugs should wait five years more to have practical applications (Com Ciência, 2002 c).

The hard disposition from the United States to effectively invest in the area "catalyzed" a reaction from European Community countries and Japan, initially, and from other countries, lately, leading to the assemblage of many other ambitious national programs, based on the acknowledge that nanotechnology would be of large importance within a close future for industrialized nations and for those countries "on the course of" becoming industrialized (Alves, 2004).

\section{Japan}

The application of nanotechnology into biomedical areas, including the diagnosis, pharmaceutical products and related areas, was strongly emphasized in the national programs/initiatives of nanotechnology in Asian countries. The government has put efforts to coordinate national programs and promote interdisciplinary collaborations. In Japan, Korea and Taiwan, the fusion of information technology, biotechnology and nanotechnology is particularly explicit in their specific policies of Science and Technology. The projects related to nanotechnology in Asia, including China, Japan, Korea and Taiwan, cover topics such as diagnosis (molecular detection including biochips, "lab-on-a-chip", proteinic chips, sensors, genetic therepy and imaging), drug delivery systems (DDS), regenerative medicine (stem-cells and tissue engineering) and medical devices.

The Japanese government and companies have engaged themselves to promote the research, development and market of nanotechnology. The Third Basic Plan of Science and Technology (2005) emphasized five main strategies for the next five years of Science and Technology development in the country. The five strategic areas are: 1 . Strategy of Human Resources, including the creation of a diversified and integrated education program, encouraging women, utilizing the expertise from seniors and importing excellent foreign scientists to Japan; 2. Strategy of Fundamental Research, with the purpose to diversify areas of fundamental research, assuring the allocation of competitive funding in these areas at universities and enforcing infrastructures; 3. Strategy of Innovation, focused in four prioritized areas including Biotechnology, Environmental Technology, Nanotechnology and Informatics and their fusion areas, in order to create social and economical values for the innovations, assuring the commercialization of the original research results and reinforcing the cooperation among industry-government-academy; 4. Strategy of Basic Nucleus Technology, that develops the characteristic nucleus of national nanotechnology, to assure long term and sustainable development to areas of integrated Earth observation and monitoring systems in global scale, spatial transportation systems, petaflop supercomputer, high speed protein factory and others; 5 . International Strategy, promoting international activities including the establishment of an attractive research environment, importing excellent foreign human resources, enforcing the dissemination of information and taking the lead to establish the Eastern Asia Community (Asia, 2005a).

The government funding agencies have worked close to companies, as well as R\&D communities, to understand the status of national and international development and the Japanese companies competitiveness in several sectors in which nanotechnology is relevant, especially the areas of Information Technology/Electronics, Environment/Energy/Fuel Cells, Metrology, Precision Engineering/Advanced Manufacturing, Space, Materials/ Advanced Coatings and Biomedical and Health Care (Asia, 2005b). The last one has become one of the greatest application targets of Japanese nanotechnology.

In Japan, besides the advanced manufacturing technologies for Japanese companies, another target of nanotechnology is its application on the improvement of population health. The nanobiotechnology has transformed itself into a priority within the Japanese policy of Science and Technology. The government started a coordinated effort in 2003, following a study conducted by the Ministry of Economy, Trade and Industry (METI) about nanobiotechnology trends and their application in industry. The METI has immediately launched different nanobiotechnological projects under the 'Focused 21 Program' conducted by Japanese companies such as Olympus, Toray, NEC, Shimazu and others. The projects had duration of four years (2003 - 2006), with investments varying from 1.4 to 17.1 million dollars only for the year of 2005 (Asia, 2005c).

To promote even more the nanobiotechnology companies in Japan, the METI has established the 'NanoBio Working Group and Industry Committee' to investigate the status of nanobiotechnology industry in Japan and foreign parts, and to formulate the map in collaboration with Japanese companies, universities and national institutions, as well as the "think-tank" organizations, such as the Mitsubishi Institute of Research. The Ministry of Education, Sports, Culture, Science and Technology (MEXT) gives priority also to nanobiotechnology in its policy of science and technology. The nanobiotechnology projects are funded under many schemes, including the 'Science 
and Research Grant Assistance', '21st Century Center of Excellence' (COE) and the 'Science and Technology Promotion Funds'. In particular, the COE is a program of five years with the budget between $1-5$ million dollars per year per project.

In Japan, more than $80 \%$ of nanotechnology companies actively conducting R\&D and Nanotechnology business are great companies, with more than 10 million dollars of capital and more than 1000 employees. The Japanese understand that nanotechnology requires expensive long term investments in infrastructure and $\mathrm{R} \& \mathrm{D}$, in order to achieve the commercialization stage, which is obviously more difficult to small and middle companies (less than 300 employees and capital lower than three million dollars) than to larger companies (Asia, 2005d).

Since 2000, the investment in nanobiotechnological areas, such as drugs delivery systems (DDS), and applications of nanomaterials, such as the carbon nanotubes, are becoming popular. In 2001, a great number of corporations in Japan have created a nanotechnology fund dedicated to business and R\&D in this area. The two largest ones, Mitsubishi Corporation and Mitsui \& Co, launched a fund of 150 million dollars for the development of business in nanotechnology for five years (Asia, 2005e).

Despite the Japanese government impelling to a stronger industry-government-university collaboration, the challenges remain, such as the ownership of intellectual property, the sufficient comprehension of mutual objectives and the development objectives (Asia, 2005d). The nanotechnology is still in the basic research phase and in the level of research and development of products.

Experts of the area have done recommendations to Japanese politicians respecting to improvement and construction of infrastructures or establishment of new systems to accelerate the nanotechnology commercialization, in order to improve the competitiveness of Japanese R\&D and industry.

\section{European Union}

Europe is one of the leading actors in nanoscience and nanotechnology in strict research and in technological development, thanks to its investigators' creativity; to initiatives from its industry, universities and research organizations; to its quality infrastructure and to the commitment of its public authorities. During the last two decades, the European Union (EU), through the 'Framework Programmes' (FP), has had a support policy to science and technology targeting essentially the incentive for cooperation between European investigators.
In 2000 March, the European Council of Lisbon adopted the European Research Area (ERA), establishing the foundation for a common science and technology policy through European Union (European Commission, 2007).

During the EuroNanoForum 2003 occurred in Trieste, Italy, with more than a thousand participants, it was formed the conception of an integrated and responsible action in nanotechnology. This was followed by the publication of a communicate "Towards an European Strategy of Nanotechnology" by the European Commission in May 2004 (Nanoforum, 2004a).

Including the visions from various interested parts, this integrated and responsible strategy has highlighted the necessity of conjunct actions in:

- $\quad$ increasing the investments and coordination of R\&D to reinforce the industrial exploration of N\&N together with excellence and scientific competition;

- developing a worldwide competitive infrastructure of R\&D ("poles of excellence") that takes into account the necessities coming from the industry, as well as those from the research organizations;

- promoting the education and interdisciplinary training of investigators together with a stronger enterprising mentality;

- $\quad$ promoting favorable conditions for industrial innovation, in order to assure that $R \& D$ are translated into accessible and safe products and processes for wealth creation;

- $\quad$ respecting ethical principles, integrating social considerations in the $R \& D$ process in its initial stage and encouraging the dialog with citizens;

- directing the public health to safety and occupational health, environmental risks and those of consumers of products based in N\&N in the initial stage; complementing the above actions with appropriate cooperation and initiatives at international level (Tomellini, Monk, 2005).

On September $24^{\text {th }}, 2004$, the Competitiveness Council has published a report about its conclusions respecting to nanotechnology. In this report, the Council recognizes the importance of N\&N in several areas; remembers the strategy of creation of ERA (European Research Area); endorses the integrated and responsible strategy of communication "Towards an European Strategy of Nanotechnology"; and accepts the intension of European Commission to develop a Plan of Action during the first quarter of 2005, after a great discussion with the several interested parts and engaging itself in an international level dialog, with the vision of establish a structure of shared principles for the development and use 
of nanotechnology in a safe, maintainable, responsible and social way (Council, 2004).

Nowadays, the majority of European countries have the projects or initiatives sponsored by EU. Among them there are the European Framework Programmes (FP), with are programs projected to reinforce and expand the research and development in Europe (Nanoforum, 2004b).

Based on the Accord that established the European Union, the FP have to follow two main strategic objectives: to reinforce the scientific and technologic bases of industry and to encourage the international competitiveness, while promoting research activities to support other EU policies. The FPs are the main tool of EU for the funding of research in Europe, being proposed by European Commission and adopted by the Council and by European Parliament through a process of conjunct decision. The FPs have been implemented in 1984 and every FP comprehends a period of five years, including the last year of previous FP and the first year of following FP. Between the prioritized areas of sixth FP (FP6), which was in force between 2002 and 2006, were those of "Nanotechnology and nanoscience, Multifunctional materials based on knowledge and New processes and production artifices" - NMP (Cordis, 2007a).

The Figure 2 shows the areas of higher governmental investment in nanotechnology at EU. The fourth FP(FP4) was in force between 1994 and 1998, and the fifth FP (FP5), from 1998 to 2002. The percentage of investments in nanobiotechnology has grown between one FP and the following one.

With budged of $€ 1,429$ million for $2002-2006$, the priority of NMP (Nanosciences Nanotechnologies, Materials, Processes) within the FP6 was to promote the transition toward "knowledge-based" products and services, with the discovery of new applicable knowledge in the long term (Cordis, 2007b).

The governmental support for the research in N\&N has recently increased in all countries. The average rates of yearly growth differ from $-10 \%$ in Denmark to $+55 \%$ in Italy and $213 \%$ in Ireland. The accentuated increase in Ireland was caused by the launch of a special program of nanotechnology in 2000. For Europe, as a total, the average rate yearly growth is of $12 \%$ (European Commission, 2003).

A report of 2004 from the European Science Foundation suggests that these funding mechanisms are not adequate for the development of nanobiotechnology. The programs structure and the diversity of funding sources (for instance, from European Union, national, regional and other entities) make the path to funding more sinuous. Another limiting factor is the fact that many resources are given for the traditional scientific disciplines, which could exclude interdisciplinary researches or those with many interfaces. In many cases, the funding is restrained because the project requires a partnership with the industry. There are also some cases in which the selection criteria could be political, instead of based on scientific excellence.

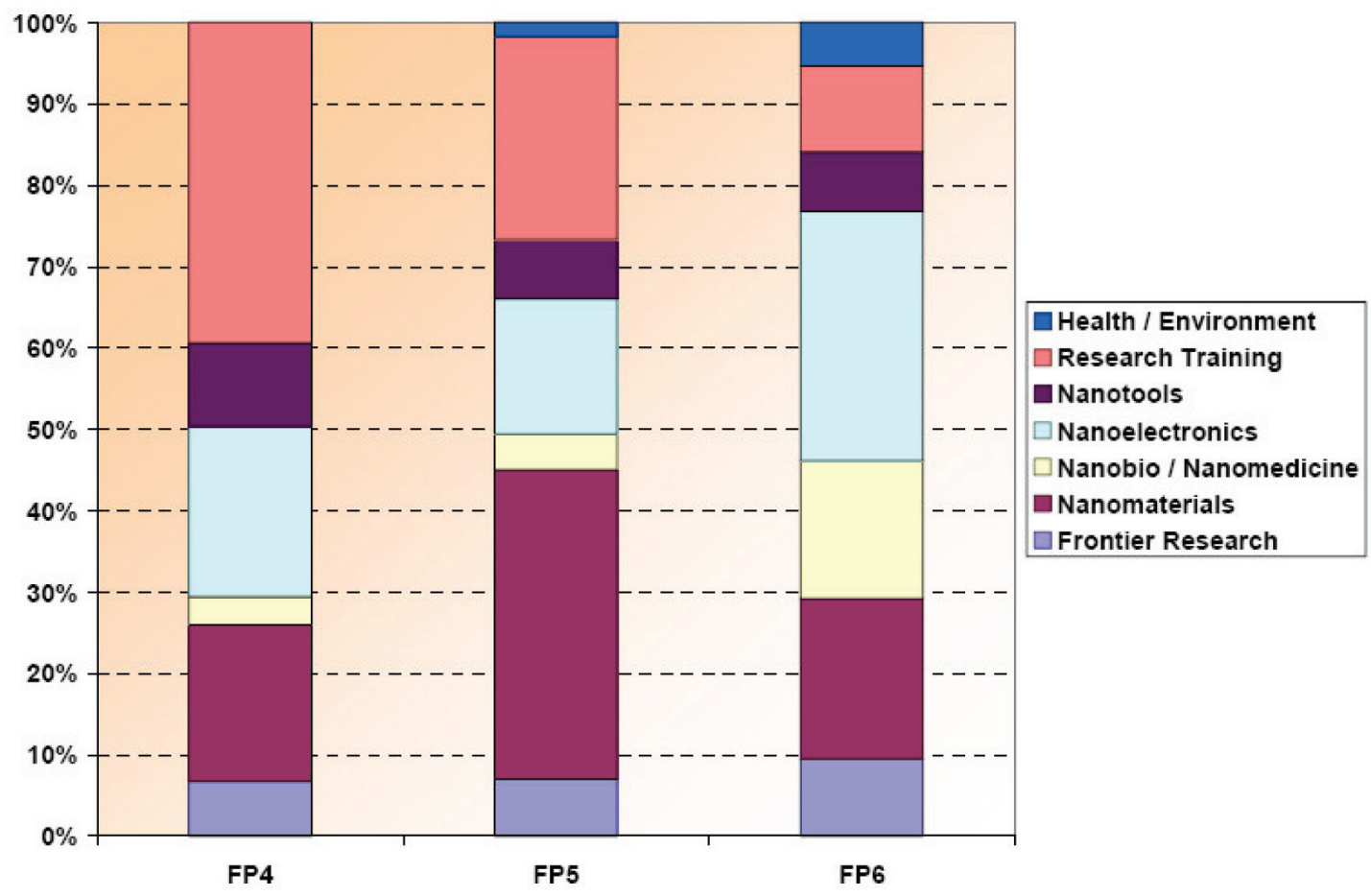

FIGURE 2 - Areas of R\&D in Nanotechnology supported by successive FPs. Source: Unit G4, 2005. 


\section{DEVELOPMENT OF NANOTECHNOLOGY IN BRAZIL}

The concern for this new technology in Brazil has concretized itself with the establishment of the Program of Development of Nanotechnology and Nanoscience within the Pluriannual Plan of 2004 - 2007, whose bases were given by the proposal of the Work Group (GT) created by Ordinance MCT-252 of 2003. The government has elected, from that occasion on, the Nanotechnology and Biotechnology as focuses of its policies for the industrial development. Such areas were identified as those that will bring a new technological revolution, accompanying an international movement in the main countries of technological development (Instituto, 2005).

The initiative has emerged from the need to create an ample program for research and development in nanotechnology, maximizing the existing resources utilization, creating and reinforcing similar laboratories, capacitating and training human resources, integrating the competences in the area and supporting the competitiveness of different segments of industry (Ministério, 2004).

This interministerial program, captained by MCT (Ministério da Ciência e Tecnologia) and involving different public and private institutions, focuses on the research and development, the creation of human capacity (developing new talents), the provision of infrastructure (laboratories, etc.) as well as the study of potentialities for commercialization and innovation. The public and private Institutions that participate in the Program of Development of Nanotechnology and Nanoscience are: Ministry of Science and Technology (providing resources for R\&D from $\mathrm{CNPq}$ and FINEP), Ministry of Development, Industry and Foreign Commerce (through its organs: INPI, BNDES, INMETRO), Ministry of Education (involve in the CAPES), Ministry of Health (with the DECIT, FIOCRUZ, ANVISA), Ministry of Agriculture, Livestock and Supplying (through the EMBRAPA), Ministry of Defense (with the technological centers of Aeronautics, Army and Marine), CNI (Confederação Nacional da Indústria or National Confederation of Industry), SENAI (Serviço Nacional de Aprendizagem Industrial or National Service of Industrial Apprenticeship) and SEBRAE (Serviços de Apoio às Micro e Pequenas Empresas or Service of Support to Micro and Small Companies).

The purpose of the program is to create and develop new products and processes in nanotechnology to increase the competitiveness of national industry; and to capacitate personnel for the utilization of the economic, technological and scientific opportunities of nanotechnology (Ministério, 2004).

To achieve the aforementioned objectives, the program aims:

- To establish clear and objective policies, which create a favorable investment environment;

- $\quad$ To provide the necessary long term resources for the constitution of capacities;

- To establish a regulatory structure to assure the social welfare and the competitiveness;

- $\quad$ To encourage other agents to conjunct public-private partnerships in the development of products and processes (Instituto, 2005).

The GT has presented in its project the following budgetary demands for resources from the national treasure and/or other sources, including the Sectorial Funds, necessary for the execution of the Program, presented at Table II.

To these resources should be summed resources from companies and state or regional organs, especially for the activities of research and development in nanoscience and nanotechnology.

The functioning form of the program was thought to operate in networks. Initially, the proposal elaborated by GT anticipated the structuring of six networks, being that four were already in operation (Nanobiotechnology Network, Nanostructured Materials and Thin Films Network, Nanodevices and Semiconductor Materials Network and Molecular Nanotechnology and Interfaces Network),

TABLE II - Budgetary demands for the Program of Development of Nanotechnology and Nanoscience

\begin{tabular}{lccccc}
\hline Item & \multicolumn{4}{c}{ Budgetary demands (thousand reais/year) } \\
\cline { 2 - 6 } & 2004 & 2005 & 2006 & 2007 & Total \\
\hline Implantation of laboratories and nanotechnology networks & 71.130 & 71.130 & 71.130 & 71.130 & 284.520 \\
Support to networks and nanotechnology laboratories & 3.720 & 5.999 & 9.012 & 11.278 & 30.000 \\
Program management & 350 & 350 & 350 & 350 & 1.400 \\
R\&D in nanoscience and nanotechnology & 21.500 & 21.500 & 21.500 & 21.500 & 86.000 \\
Total & 96.700 & 98.970 & 101.992 & 104.258 & 401.920 \\
\hline
\end{tabular}

Source: Ministério da Ciência e Tecnologia, 2004 
being then necessary to create two new networks (Nanoanalysis and Diagnosis Network and Nanometrology and Instrumentation Network).

Among the networks supported by the program, the one that has direct application to health area was the Nanobiotechnology Network, coordinated by UNICAMP/ UMC (Universidade Estadual de Campinas/Universidade de Mogi das Cruzes) from 2001 up to 2004.

The goals of the Nanotechnology Network were the technological development and innovation for foreign competition; to execute research, development and innovation projects favoring the interaction between laboratories and companies, as well as favoring the value and technology aggregation into industrial products. The targets consist, in short term, in the identification of companies with affinity for nanobiotechnology; the establishment of partnership between companies and laboratories; the proposal of management models and administrative structure for the network; and, in long term, the attraction of companies and investors for nanobiotechnology projects and supporting the creation of innovative companies (Ministério, 2007).

This network has produced a total of 713 publications and has obtained 25 approved patents from 2001 to 2003. Some examples of projects already developed by the network and whose products were passed to the industry are:

- $\quad$ PROJECT: "Encapsulation of antihypertensive in cyclodextrins" (UFMG). Company: BIOLAB FARMACÊUTICA S.A. The company acquires from UFMG the right to produce antihypertensive with the technique of controlled release of drug;

- $\quad$ PROJECT: "Biosensors for determination of coffee quality” (EMBRAPA). Company: ASSOCIAÇÃO BRASILEIRA DAS INDÚSTRIAS DO CAFÉ (ABIC);

- $\quad$ PROJECT: "Utilization of immunemodulator in immunodepressed patients/animals" (UMC/UNICAMP). Company: BIOLAB FARMACÊUTICA S.A. (Rede, 2003).

On August $19^{\text {th }}, 2005$, it was launched the National Program of Nanotechnology (Programa Nacional de Nanotecnologia - PNN) by President Luiz Inácio Lula da Silva and by the Minister of Science and Technology, Sérgio Rezende, during a visit to the National Laboratory of Sincrotron Light (Laboratório Nacional de Luz Síncrotron-LNLS), in Campinas-SP, an organ linked to Ministry of Science and Technology (MCT). The PNN, composed by a conjunction of actions supported by budgetary resources from the 2004 - 2007 PPA (Plano Plurianual or Pluriannual Plan) and Sectorial Funds, has the purpose to meet the strategic demands identified by the community involved with the nanoscience and nanotechnology development and to put into practice one of the measures of the Industrial, Technological and Foreign Commerce Policy (Política Industrial, Tecnológica e de Comércio Exterior - PITCE) (Ministério do Desenvolvimento, Indústria e Comércio Exterior, 2008).

With the publication of the Edictal MCT/CNPq 29/2005, the existing networks were restructured and new networks were created. According to the Reporting Referring to Management of Program "Development of Nanoscience and Nanotechnology" in the Assignment of 2005, which was elaborated by the Secretariat of Technological Development and Innovation of the Ministry of Science and Technology, there are ten nanotechnology networks being supported by the program: Simulation and Modeling of Nanobiostructures (USP); Network of Nanophotonics (UFPE); National Network of Nanobiotechnology and Nanostructured Systems - Nanobiostructures (UFRN); Cooperative Network of Research in Nanostructured Coatings (PUC/RJ); Probes Scanning Microscopy - Open Software and Hardware (LNLS); Carbon Nanotubes: Science and Applications (UFMG); Nanoglucobiotechnology (UFPR); Molecular Nanotechnology and Interfaces Network - Stage I, II (UFPE); Nanobiomagnetism Network (UNB), and Nanocosmetics: from the Conception to Technological Applications (UFRGS). These networks are at initial phase of execution and their activities are concentrated in the equipment acquisition, integration and implementation of adequate infrastructure (Ministério, 2005).

In the new structure, the nanobiotechnology is coordinated by Federal University of Rio Grande do Norte. Until the present moment, consolidated reports about the performance of this network, containing the total number of teachers and post-graduation students involved in research projects from the nanobiotechnology network, as well as the total number of published articles and granted patents, are not yet available.

Entities from all over the country are part of the nanotechnology networks; however, there is a lower concentration of projects from the northern and centralwestern region. According to results from the last edictal of National Council of Scientific and Technological Development (Conselho Nacional de Desenvolvimento Cientifico e Tecnológico- $\mathrm{CNPq}$ ) referring to public selection of research project proposals, presented by young investigators for funding of research and development activities in Nanoscience and Nanotechnology (Edital FVA/MCT/ $C N P q n^{\circ} 09 / 2007$ ), out of 45 approved projects, only 4 were from the central-western and northern region (two of every region). This difference can also be observed in the edictal of public selection of research and development 
project proposals turned to improvement of laboratory infrastructure in nanotechnology: out of 12 approved proposals, 7 were from southwestern region, 3 from southern region, 2 from northeastern region and none proposal from northern or central-western region (Conselho, 2007a, b). This shows the evident correlation between the regional technological-scientific development and the organization of nanotechnology networks in the country.

\section{CONCLUSIONS}

As reported, the nanotechnology is still in its initial phase of development all over the world. However, it is already established that its contribution in all areas of knowledge will enormously increase in the very near future.

The nanotechnology will bring many economic opportunities for the countries that invest in C\&T\&I. Because of that, the investments trend in this area is progressively growing all over the world. One of the major impacts of nanotechnology will be in health, more specifically in the pharmaceutical field, with the development of nanodrugs.

It was observed that in countries of more advanced technology, such as USA, Japan and EU, the investments in nanotechnology from both private and public sources are growing year by year.

This new technology is creating a natural dominium of interdisciplinary interactions and triggering a revision in the universities curricular frames, creating new educational paradigms. There is great concern regarding the formation of professional experts in the area and the translation of technology developed by universities and research institutes to industry. It was noticed that the European Union is facing a problem of evasion of nanotechnology expert investigators to the USA.

In Brazil, the study has shown that despite the growing concern of investigators and national research or funding centers with nanotechnology investigation, larger investments and formation of expert professionals in the area are still needed. Government and private sectors should invest more in nanotechnology R\&D. Another observed problem is that nanotechnology investments in Brazil are excessively concentrated, essentially, in the southwestern region. For a larger advancement in this area, it is important to involve all country regions in this entrepreneurship, mainly the regions of lower technological development, such as northern and centralwestern country.

The experience from countries of more advanced technology could be transformed in excellent example for Brazil, by utilizing the positive aspects and potentialities of such programs, and avoiding some of their mistakes and deficiencies.

\section{ACKNOWLEDGEMENTS}

To Professor Dr. Rafael Villa, from the Faculty of Public Health / University of São Paulo, for his valuable orientation in the monograph that grounds this manuscript, and Dr. Camila Fracalossi Rediguieri, from National Agency of Health Surveillance, for her kind revision of this manuscript.

\section{REFERENCES}

ALVES, O.I. Nanotecnologia, nanociência e nanomaterias: quando a distância entre o presente e o futuro não é apenas uma questão de tempo. Parcerias estratég., v.18, p.1-248, 2004.

ASIA PACIFIC NANOTECH WEEKLY ${ }^{a}$, Vol.3, artigo ${ }^{\circ}$ 28, 2005. Available at: <http://www.nanoworld.jp/apnw/ articles/3-28.php $>$ Accessed on: 10 feb. 2007.

ASIA PACIFIC NANOTECH WEEKLY ${ }^{b}$, Vol.3, artigo ${ }^{\circ}$ 38, 2005. Available at: <http://www.nanoworld.jp/apnw/ articles/3-38.php> Accessed on: 10 feb. 2007.

ASIA PACIFIC NANOTECH WEEKLY. v.3, artigo no 42, 2005. Available at: $<$ http://www.nanoworld.jp/apnw/articles/3-42. php > Accessed on: 10 feb. 2007.

ASIA PACIFIC NANOTECH WEEKLY ${ }^{\mathrm{d}}$, Vol.3, artigo ${ }^{\circ}$ 37, 2005. Available at: <http://www.nanoworld.jp/apnw/ articles/3-37.php $>$ Accessed on: 10 feb. 2007.

ASIA PACIFIC NANOTECH WEEKLY ${ }^{e}$, Vol.3, artigo ${ }^{\circ}$ 34, 2005. Available at: <http://www.nanoworld.jp/apnw/ articles/3-34.php> Accessed on: 10 feb. 2007.

BUDGET OF THE UNITED STATES GOVERNMENT. Analytical perspectives, fiscal year 2007. Available at: URL: $<$ http://www.whitehouse.gov/omb/budget/fy2007/pdf/spec. pdf> Accessed on: 10 feb. 2007.

COM CIÊNCIA. Nanobiotecnologia e saúde. 2002. Available at: $<$ http://www.comciencia.br/reportagens/nanotecnologia/ nano15.htm $>$. Accessed on: 10 feb. 2007a.

COM CIÊNCIA. Rede de pesquisa em nanotecnologia. 2002. Available at $<$ http://www.comciencia.br/reportagens/ nanotecnologia/nano20.htm $>$. Accessed on: 10. feb 2007b. 
COM CIÊNCIA. Nos EUA, investimentos podem alcançar os do genoma. 2002. Available at: <http://www.comciencia. br/reportagens/nanotecnologia/nano06.htm $>$ Accessed on: 10 feb. 2007 c.

CONSELHO NACIONAL DE DESENVOLVIMENTO CIENTÍFICO E TECNOLÓGICO. Edital FVA/MCT/ CNPq $n^{\circ}$ 09/2007. 2007. Available at: <http://www.cnpq. br/resultados/2007/009.htm $>$ Accessed on: 24 jun. 2008a.

CONSELHO NACIONAL DE DESENVOLVIMENTO CIENTÍFICO E TECNOLÓGICO. Edital CT-Petro/FVA/ MCT/CNPq $n^{\circ}$ 10/2007. Available at: <http://www.cnpq. br/resultados/2007/009.htm $>$ Accessed on: 24 jun. 2008.

CORDIS. Sixth framework programme. Available at: $<$ http:// cordis.europa.eu/fp6/fp6_glance.htm\#> Accessed on: 10 feb. 2007a.

CORDIS. Nanotechnology and nanosciences, knowledge-based multifunctional materials and new production processes and devices. Available at: < http://cordis.europa.eu/nmp/ home.html> Accessed on: 10 feb. 2007 b.

COUNCIL OF EUROPEAN UNION. Competitiveness (Internal Market, Industry And Research). 2605 th Council Meeting. Brussels, 2004. 34 p.

DOS ANJOS, M.A.; TAVARES, E.T; MENDES, A.S. Relatório sobre a inclusão de nanotecnologia no fundo setorial de petróleo e gás (CT-PETRO). Brasília, 2004. 25p.

ETC GROUP. Manual de bolso das tecnologias em nanoescala e a teoria do "little bang". 2005. Available at: <http:// www.etcgroup.org/upload/publication/57/01/tinyp_ portuguesfinal.pdf $>$ Accessed on: 10 feb. 2007.

EUROPEAN COMISSION. European Research Area. 2007. Available at: <http://ec.europa.eu/research/era/leaflet/en/ preface_en.html $>$ Accessed on: 10 feb. 2007.

EUROPEAN COMISSION. Third european report on science \& technology indicators. Brussels: Office for Official Publications of the European Communities, 2003. 451p.

EUROPEAN SCIENCE FOUNDATION. Nanomedicine. An ESF-European Medical Research Councils (EMRC) Forward Look Report. Strasburg: IREG, 2004. 52 p.
GALEMBECK, F. Organização de pesquisa no Brasil: lições do passado, propostas para o futuro. Quim. Nova, v.28, número?, p.S52-S55, 2005

INOVAÇÃO UNICAMP. Depoimento de Richard Russel, do governo dos EUA, aos deputados, sobre a politica da administração Bush para o fomento de P\&D em nanotecnologia. 2004. Available at: <http://www.inovacao. unicamp.br/especial/nanotech/inte-russel.html $>$ Accessed on: 10 feb. 2007.

INSTITUTO DE ESTUDOS PARA O DESENVOLVIMENTO INDUSTRIAL. Carta IEDI n. 165 - O Brasil e o Desafio da Nanotecnologia. 2005. Available at: <http://www.iedi. org.br/cgi/cgilua.exe/sys/start.htm?sid=20\&from_info_ index=11\&infoid=1358> Accessed on: 10 feb. 2007.

MINISTÉRIO DA CIÊNCIA E TECNOLOGIA. Desenvolvimento da nanociência e da nanotecnologia. Proposta do Grupo de Trabalho criado pela Portaria MCT $\mathrm{n}^{\mathrm{o}} 252$ como subsídio ao Programa de Desenvolvimento da Nanociência e da Nanotecnologia do PPA 2004-2007. 2004. Available at: <http://www.mct.gov.br/upd_blob/2361.pdf $>$ Accessed on: 10 feb. 2007.

MINISTÉRIO DA CIÊNCIA E TECNOLOGIA. Rede nanobiotec. 2007. Available at: < http://www.mct.gov.br/ upd_blob/7565.pdf $>$ Accessed on: 10 feb. 2007.

MINISTÉRIO DA CIÊNCIA E TECNOLOGIA. Relatório referente à gestão do programa "desenvolvimento da nanociência e da nanotecnologia" no exercício de 2005. Available at: <http://www.mct.gov.br/upd_blob/2705.pdf $>$ Accessed on: 10 feb. 2007.

MINISTÉRIO DA CIÊNCIA E TECNOLOGIA. Programa Nacional de Nanotecnologia. 2008. Available at: < http:// www.mct.gov.br/index.php/content/view/27137.html> Accessed on: 24 jun. 2008.

NANOFORUM. Outcome of the open consultation on the European strategy for nanotechnology. 2004. Available at: < http:// www.nanoforum.org/dateien/temp/nanosurvey6.pdf $>$ Accessed on: 10 feb. 2007a.

NANOFORUM. Nanotechnology in the EU-bioanalytical and biodiagnostic techniques. 2004. Available at: <http://www. nanoforum.org $>$ Accessed on: 10 feb 2007b. 
REDE NACIONAL DE NANOBIOTECNOLOGIA. Campinas, 2003. Available at: $<$ http://www.nanobiotec.iqm.unicamp. br/> Accessed on: 10 feb. 2007.

ROSZEKI, B.; DE JONGA, W.H.; GEERTSMA, R.E. Nanotechnology in medical applications:state-of-the-art in materials and devices. Bilthoven, 2005. 123 p. (RIVM Report 265001001).

THE NATIONAL NANOTECHNOLOGY INITIATIVE. Research and development leading to a revolution in technology and industry. Supplement to the president's 2007 budget. 2006. Available at: <http://www.nano.gov/ nni_07budget.pdf $>$ Accessed on: 10 feb. 2007.

\section{THE NATIONAL NANOTECHNOLOGY INITIATIVE.}

Strategic plan. 2004. Available at: <http://nano.gov/ nni_strategic_plan_2004.pdf $>$ Accessed on: 10 feb. 2007.
TOMELLINI, R.; MONK, R. A European approach to nanotechnologies. GAIA, Brussels, v.14, número?, p. 28$29,2005$.

UNIT G4 NANOSCIENCES AND NANOTECHNOLOGIES EUROPEAN COMMISSION. Some figures about nanotechnology $R \& D$ in Europe and beyond. 2005. Available at: <ftp:/ftp.cordis.europa.eu/pub/nanotechnology/docs/ nano_funding_data_08122005.pdf $>$ Accessed on: 10 feb. 2007.

Received for publication on $28^{\text {th }}$ march 2008 Accepted for publication on $10^{\text {th }}$ october 2008 